Filozofska fakulteta, Univerza v Ljubljani

Slovenija

mojca.leskovec@ff.uni-lj.si

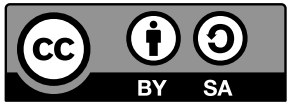

\title{
DEUTSCH ALS FREMDSPRACHE IM KINDESALTER
}

Retelj, Andreja/Kosevski Puljić, Brigita (2020): Deutsch als Fremdsprache im Kindesalter. Ljubljana: Znanstvena založba Filozofske fakultete. ISBN: 978-961-06-0395-5, mehka vezava, 76 strani, $8,90 €$.

Univerzitetni učbenik Deutsch als Fremdsprache im Kindesalter (slov. Nemščina kot tuji jezik v otroštvu) avtoric Andreje Retelj in Brigite Kosevski Puljić glede na trenutno politiko (ne)zaposlovanja diplomantov in diplomantk jezikovnih programov pedagoških smeri kot učiteljev in učiteljic tujih jezikov v prvi triadi osnovnega šolstva za matično fakulteto predstavlja pomemben prispevek $\mathrm{k}$ razvoju strateško pomembnega področja poučevanja tujih jezikov v zgodnjem in srednjem otroštvu. Delo pri tem presega okvire ciljne skupine študentov in študentk pedagoške smeri drugostopenjskega študijskega programa nemščina pri izbirnem predmetu Zgodnje učenje in poučevanje nemščine v obsegu treh kreditnih točk, saj s svojo vsebino prav tako naslavlja učitelje in učiteljice nemščine kot tujega jezika v šolski praksi; čeprav spisano v nemškem jeziku, pa je priporočljivo pregledno branje in vir praktičnih idej za izvedbo učnih ur tudi za (bodoče) učitelje in učiteljice drugih tujih jezikov.

Prvo poglavje učbenika tematizira razliko med učenjem in usvajanjem jezikov ter usvajanje tujega jezika prikazuje z razvojnopsihološkega in antropološkega vidika, kot tudi z vidika pedagogike in nevroznanosti. Pri tem ne pozabi izpostaviti pomembne vloge zgodnjega učenja tujih jezikov pri razvoju pozitivnega odnosa do drugih kultur in drugače mislečih. Odgovarja na vprašanje, kako se v splošnem učijo otroci, in to prenaša na področje učenja tujih jezikov, pri tem pa opozarja tudi na izjemen pomen učiteljskega lika za uspešno učenje.

Drugo poglavje se posveča teorijam usvajanja jezika in obstoječim hipotezam o njem. Njihovo skupno število in raznovrstnost nakazujeta kompleksnost procesa učenja tujega jezika, ki učiteljem in učiteljicam v šolski praksi narekuje ne le premišljeno pripravo dejavnosti v razredu, temveč po njihovi izpeljavi tudi temeljito refleksijo. Avtorici dalje predstavljata notranje in zunanje dejavnike usvajanja jezika ter razvojne stopnje, $\mathrm{v}$ 
zadnjem delu poglavja pa se dotikata večjezičnosti in uresničevanja načela raznojezičnosti pri pouku tujega jezika v zgodnjem in srednjem otroštvu.

Tretje poglavje je namenjeno didaktično-metodičnim načelom zgodnjega poučevanja tujih jezikov. Naslanjajoč se na nürnberška priporočila, sistematično prikazuje načela, ki se nanašajo na učne cilje in vsebine, interakcijo v razredu, učne procese, učno okolje in vzdušje ter učna gradiva, pri čemer avtorici poudarjata, da načela ne predstavljajo praktičnih nasvetov za pouk, temveč je, izhajajoč iz trenutno veljavnih načel, kaj in kako vselej avtonomna odločitev učitelja oz. učiteljice, saj prav ta najbolje pozna svoje učence in učenke.

Četrto poglavje niza in opisuje najpogosteje uporabljane metode in tehnike zgodnjega usvajanja tujega jezika. Avtorici ob tem opozarjata, da izbira metode oziroma tehnike ni zagotovilo, da bo učenje tujega jezika uspešno, saj je za to potrebno izpolnjevanje vrste drugih že predstavljenih dejavnikov. Poglavje ponuja tudi nabor dodatne literature za poglabljanje znanja in vrsto uporabnih idej za pouk.

Peto poglavje obravnava vlogo vrednotenja in ocenjevanja znanja pri zgodnjem poučevanju tujih jezikov. Podaja priporočila zanju in predlaga nabor možnosti za njuno smiselno uresničevanje, dotika pa se tudi odnosa do napak v procesu učenja ter preverjanja naučenega.

Odlike predstavljenega dela so zgoščen prikaz relevantnih teoretičnih spoznanj s področja učenja in poučevanja tujih jezikov v zgodnjem in srednjem otroštvu, pregledna zasnovanost, sistematično podajanje teorije in njeno neposredno sprotno povezovanje s prakso v obliki priporočil za šolsko prakso, idej za izpeljavo pouka, nalog za samostojno raziskovanje in preizkušanje ter refleksijo. Kot avtorici poudarjata na več mestih, namreč znanje o zgodnjem poučevanju za uspešno poučevanje ni dovolj; veliko vlogo igra osebnost učitelja oz. učiteljice, osrednjega pomena pa je temeljita priprava, saj so otroci zelo hvaležno, a tudi izjemno kritično občinstvo. 